\title{
Single-crystal X-ray diffraction study of synthetic sodium-hydronium jarosite
}

\author{
Jens Najorka ${ }^{1}$ (1) $\cdot$ James M. T. Lewis $^{2} \cdot$ John $^{\text {Spratt }^{1}} \cdot$ Mark A. Sephton $^{2}$
}

Received: 5 November 2015 / Accepted: 21 January 2016 / Published online: 24 February 2016

(C) The Author(s) 2016. This article is published with open access at Springerlink.com

\begin{abstract}
Na}-\mathrm{H}_{3} \mathrm{O}$ jarosite was synthesized hydrothermally at $413 \mathrm{~K}$ for 8 days and investigated using singlecrystal X-ray diffraction (XRD) and electron microprobe analysis (EMPA). The chemical composition of the studied crystal is $\left[\mathrm{Na}_{0.57(3)}\left(\mathrm{H}_{3} \mathrm{O}\right)_{0.36}\left(\mathrm{H}_{2} \mathrm{O}\right)_{0.07}\right]^{\mathrm{A}} \mathrm{Fe}_{2.93(3)}\left(\mathrm{SO}_{4}\right)_{2}$ $(\mathrm{OH})_{5.70}\left(\mathrm{H}_{2} \mathrm{O}\right)_{0.30}$, and Fe deficiency was confirmed by both EMPA and XRD analysis. The single-crystal XRD data were collected at 298 and $102 \mathrm{~K}$, and crystal structures were refined in space group $R \overline{3} \mathrm{~m}$. The room-temperature data match structural trends of the jarosite group, which vary linearly with the $c$ axis. The low-temperature structure at $102 \mathrm{~K}$ shows an anisotropic decrease in the unit cell parameters, with $c$ and $a$ decreasing by 0.45 and $0.03 \%$, respectively. Structural changes are mainly confined to the $A$ site environment. Only minor changes occur in $\mathrm{FeO}_{6}$ and $\mathrm{SO}_{4}$ polyhedra. The structure responds upon cooling by increasing bond length distortion and by decreasing quadratic elongation of the large $A \mathrm{O}_{12}$ polyhedra. The structural parameters at low temperature follow very similar patterns to structural changes that correspond to compositional variation in the jarosite group, which is characterised by the flexibility of $A \mathrm{O}_{12}$ polyhedra and rigidity of $\mathrm{Fe}(\mathrm{OH})_{4} \mathrm{O}_{2}-$ $\mathrm{SO}_{4}$ layers. The most flexible areas in the jarosite structure are localized at $A \mathrm{O}_{12}$ edges that are not shared with neighbouring $\mathrm{FeO}_{6}$ octahedra. Importantly, for the application of
\end{abstract}

Jens Najorka

j.najorka@nhm.ac.uk

1 Core Research Laboratories, Natural History Museum, London SW7 5BD, UK

2 Department of Earth Science and Engineering, Impacts and Astromaterials Research Centre, Imperial College London, London SW7 2AZ, UK
XRD in planetary settings, the temperature-related changes in jarosite can mimic compositional change.

Keywords Natrojarosite $\cdot$ Hydronium jarosite . Crystal structure $\cdot$ Single-crystal X-ray diffraction $\cdot$ Low temperature $\cdot$ Mars

\section{Introduction}

Jarosite group minerals are members of the alunite supergroup, which has the general formula $A B_{3}\left(T \mathrm{O}_{4}\right)_{2}(\mathrm{OH})_{6}$. A range of cations can be incorporated into jarosite group minerals such as $A=\mathrm{Na}, \mathrm{K}, \mathrm{Ag}, \mathrm{Tl}, \mathrm{H}_{3} \mathrm{O}, \mathrm{NH}_{4}$, $\mathrm{Pb}, B=\mathrm{Fe}^{3+}$ and $T=\mathrm{S}$ (e.g. Stoffregen et al. 2000; Bayliss et al. 2010). Jarosite senso stricto [ $\mathrm{K}$ jarosite, $\left.\mathrm{KFe}_{3}\left(\mathrm{SO}_{4}\right)_{2}(\mathrm{OH})_{6}\right]$ and $\mathrm{Na}$ jarosite $\left[\mathrm{NaFe}_{3}\left(\mathrm{SO}_{4}\right)_{2}(\mathrm{OH})_{6}\right]$ are the most common jarosite species observed in nature (e.g. Desborough et al. 2010). K-deficiency is required for the formation of $\mathrm{Na}$ jarosite and alkali deficiency for the formation of $\mathrm{H}_{3} \mathrm{O}$ jarosite $\left[\left(\mathrm{H}_{3} \mathrm{O}\right) \mathrm{Fe}_{3}\left(\mathrm{SO}_{4}\right)_{2}(\mathrm{OH})_{6}\right]$.

Jarosite group minerals are mainly a product of chemical weathering. Low-temperature interaction of fluids with sulphide minerals in oxidizing and acidic environments are favourable formation conditions. On Earth, jarosite can be found in oxidation zones of sulphide-bearing ore deposits, in sediments and rocks associated with pyrite weathering, and in hydrothermally altered rocks (Dutrizac and Jambor 2000; Stoffregen et al. 2000). Jarosite group minerals are known to precipitate in acid mine drainage environment (e.g. Hudson-Edwards 2003; Jamieson et al. 2005).

Signatures of jarosite group minerals have been identified on Mars using in situ Mössbauer spectrometry by the Opportunity rover (Klingelhöfer et al. 2004). Compositions at Endurance Crater in Meridiani Planum were assigned 
to $\mathrm{K}-\mathrm{Na}-\mathrm{H}_{3} \mathrm{O}$ jarosite solid solutions with possible substitution of $\mathrm{Al}^{3+}$ for $\mathrm{Fe}^{3+}$ (Morris et al. 2006). Reflectance VIS-NIR spectra from the Mars Reconnaissance Orbiter of deposits south of Ius/Melas Chasma were assigned to nonstoichiometric $\mathrm{H}_{3} \mathrm{O}$-bearing, Fe-deficient jarosite (Milliken et al. 2013).

Surface temperatures on Mars can range between 120 and $298 \mathrm{~K}$, and crystal structure data at low temperatures can be relevant for in situ mineral identification. Only a limited number of single-crystal studies have investigated the jarosite group at low temperatures $\left(\mathrm{H}_{3} \mathrm{O}\right.$ jarositeSpratt et al. 2014; $\mathrm{K}$ jarosite-Mills et al. 2013; $\mathrm{NH}_{4}$ jarosite-Basciano and Peterson 2007). Mills et al. (2013) is the only study covering a wide low-temperature range and demonstrated that $\mathrm{K}$ jarosite undergoes a strongly anisotropic thermal expansion, with the $c$ axis changing much stronger than the $a$ axis. The anisotropic change observed for $\mathrm{K}$ jarosite is mainly related to a strong distortion of the $A \mathrm{O}_{12}$ polyhedron. Similar low-temperature effects could be inferred for $\mathrm{H}_{3} \mathrm{O}$ jarosite by comparing studies undertaken at room temperature (e.g. Majzlan et al. 2004; Plášil et al. 2014) and $173 \mathrm{~K}$ (Spratt et al. 2014). However, results from low-temperature data are still too limited to allow an extrapolation of structural mechanisms to other compositions within the jarosite group. For instance, the incorporation of smaller cations such as $\mathrm{Na}^{+}$or $\mathrm{Ag}^{+}$at the large $A$ site could induce even larger structural distortions and related unit cell anisotropies. Our study focusses on $\mathrm{Na}-$ $\mathrm{H}_{3} \mathrm{O}$ jarosite, the crystal structure of which was investigated at room temperature and $102 \mathrm{~K}$. Our observations are used to improve our knowledge of structural trends in the jarosite group and to further specify compositional and temperature induced changes of the jarosite topology.

\section{Materials and methods}

\section{Synthesis of $\mathrm{Na}-\mathrm{H}_{3} \mathrm{O}$ jarosite}

$\mathrm{Na}-\mathrm{H}_{3} \mathrm{O}$ jarosite was synthesised using a similar method as described by Basciano and Peterson (2008). A 75-ml Parr pressure vessel was used as the reaction chamber. Starting materials were $18 \mathrm{~g}$ of ferric sulphate hydrate, $0.3825 \mathrm{~g}$ of sodium sulphate and $45 \mathrm{ml}$ of deionised water. The sealed reaction vessel was placed inside a furnace and heated at $413 \mathrm{~K}$ for 8 days. The synthesis time was four times longer than described in Basciano and Peterson (2008) to promote the growth of large crystals.

\section{Electron microprobe analysis (EMPA)}

A jarosite crystal was embedded in epoxy resin and polished for EMPA. The polished cross section of the crystal was $50 \times 30 \mu \mathrm{m}$. The composition of the crystal was determined using a Cameca SX-100 electron microprobe. Column conditions used were $15 \mathrm{keV}$ and $10 \mathrm{nA}$ with an electron beam spot size of $10 \mu \mathrm{m}$. Counting times were set to $10 \mathrm{~s}$ for $\mathrm{Na}, 20 \mathrm{~s}$ for $\mathrm{S}$, and $30 \mathrm{~s}$ for Fe. Jadeite (Na), barite $(\mathrm{S})$, and hematite $(\mathrm{Fe})$ were used as standards. The PAP program was used for the matrix correction.

The chemical composition was calculated on the basis of two sulphur per formula unit (p.f.u.) and the general formula for $\mathrm{Na}-\mathrm{H}_{3} \mathrm{O}$ jarosite was $\left[\mathrm{Na}_{x}\left(\mathrm{H}_{3} \mathrm{O}\right)_{1-x-y}\left(\mathrm{H}_{2} \mathrm{O}\right)_{\mathrm{y}}\right]^{\mathrm{A}} \mathrm{Fe}_{3-y}$ $\left(\mathrm{SO}_{4}\right)_{2}(\mathrm{OH})_{6-4 y}\left(\mathrm{H}_{2} \mathrm{O}\right)_{4 y}$. The calculation of the jarosite formula followed the approach of an NMR study of Nielsen et al. (2008) suggesting that potential non-stoichiometry at the $B$ site is linked to hydronium deprotonation at the $A$ site and protonation of four hydroxyl groups per vacant $\mathrm{Fe}$ site.

Table 1 Details of data collection and structure refinement

\begin{tabular}{|c|c|c|}
\hline Structural formula & \multicolumn{2}{|c|}{$\begin{array}{l}\mathrm{Na}_{0.57}\left(\mathrm{H}_{3} \mathrm{O}\right)_{0.36}\left(\mathrm{H}_{2} \mathrm{O}\right)_{0.07} \mathrm{Fe}_{2.93} \\
\left(\mathrm{SO}_{4}\right)_{2}(\mathrm{OH})_{5.70}\left(\mathrm{H}_{2} \mathrm{O}\right)_{0.30}\end{array}$} \\
\hline$M\left(\mathrm{~g} \mathrm{~mol}^{-1}\right)$ & 479.1 & \\
\hline Temperature & $298(2) \mathrm{K}$ & $102(2) \mathrm{K}$ \\
\hline Space group & $R \overline{3} m$ & $R \overline{3} m$ \\
\hline$a(\AA)$ & $7.3270(1)$ & $7.3249(1)$ \\
\hline$c(\AA)$ & $16.7320(4)$ & $16.6575(5)$ \\
\hline$V\left(\AA^{3}\right)$ & $777.90(3)$ & $774.00(3)$ \\
\hline$Z$ & 3 & 3 \\
\hline$D_{\text {calc }}\left(\mathrm{g} \mathrm{cm}^{-3}\right)$ & 3.068 & 3.084 \\
\hline Crystal colour, habit & \multicolumn{2}{|c|}{$\begin{array}{l}\text { Yellow brown, translucent, } \\
\text { subhedral }\end{array}$} \\
\hline Crystal dimensions (mm) & \multicolumn{2}{|c|}{$0.05 \times 0.08 \times 0.10$} \\
\hline$\mu\left(\mathrm{mm}^{-1}\right)$ & 4.56 & 4.58 \\
\hline Absorption correction & Multi-scan & Multi-scan \\
\hline$T_{\min }, T_{\max }$ & $0.936,1$ & $0.940,1$ \\
\hline Diffractometer & \multicolumn{2}{|c|}{ Xcalibur with Eos CCD } \\
\hline Radiation type & \multicolumn{2}{|c|}{ Mo $K \alpha, 0.7107 \AA$} \\
\hline $\begin{array}{l}\text { Collection mode, frame width, } \\
\text { counting time }\end{array}$ & \multicolumn{2}{|l|}{$\omega$ scans, $1^{\circ}, 21 \mathrm{~s}$} \\
\hline Limiting $\theta$ angles & $3.4-33.7^{\circ}$ & $3.4-33.7^{\circ}$ \\
\hline Data Completeness $100 \%$ & To $30^{\circ}$ & To $30^{\circ}$ \\
\hline$R_{\text {int }}$ & 0.034 & 0.033 \\
\hline Limiting Miller indices & $\begin{array}{l}-11 \leq h \leq 11 \\
-11 \leq k \leq 11 \\
-25 \leq l \leq 25\end{array}$ & $\begin{array}{l}-11 \leq h \leq 11 \\
-11 \leq k \leq 11 \\
-25 \leq l \leq 25\end{array}$ \\
\hline No. of measured reflections & 6170 & 6081 \\
\hline No. of unique reflections & 413 & 413 \\
\hline No. of observed reflections & 383 & 385 \\
\hline No. of parameters & 28 & 28 \\
\hline$R_{1}[I>2 \sigma(I)], R_{1}($ all $)$ & $0.0162,0.0179$ & $0.0157,0.0184$ \\
\hline $\mathrm{w} R_{2}[I>2 \sigma(I)], \mathrm{w} R_{2}($ all $)$ & $0.0371,0.0375$ & $0.0360,0.0367$ \\
\hline $\operatorname{GooF}\left(F^{2}\right)$ & 1.110 & 1.124 \\
\hline$\Delta \rho_{\min }, \Delta \rho_{\max }\left(\mathrm{e} / \AA^{3}\right)$ & $-0.50,0.50$ & $-0.59,0.40$ \\
\hline
\end{tabular}




\section{Single-crystal X-ray diffraction}

A suitable subhedral crystal with dimensions of $100 \times 80 \times 50 \mu \mathrm{m}$ was selected for single-crystal diffraction. The single-crystal measurements were carried out using an Agilent Xcalibur single-crystal diffractometer equipped with an EOS CCD area detector. Graphite-monochromated Mo $K \alpha$ radiation was used and tube operation conditions were $50 \mathrm{kV}$ and $40 \mathrm{~mA}$. The crystal-to-detector distance was $70 \mathrm{~mm}$. Data collection was performed at 298 and $102 \mathrm{~K}$. A Cryojet system from Oxford instruments delivered a nitrogen stream in the cooling experiment at $102 \mathrm{~K}$.

For both experiments ( 298 and $102 \mathrm{~K}$ ), the frame width of the $\omega$ scans was $1^{\circ}$ and counting time per frame was $21 \mathrm{~s}$. A sphere of intensity data were collected to $60^{\circ} 2 \theta$ with $100 \%$ completeness. The intensity data were corrected for Lorentz polarization and an empirical absorption correction was applied using CrysalisRED software (Agilent Technologies). The crystal structure was solved and refined using the SHELX program (Sheldrick 2008) within the WinGX environment (Farrugia 1999). The details of data collection are given in Table 1.

\section{Results and discussion}

\section{Chemical composition}

EMPA data of seven analyses from the single crystal are listed in Table 2. The synthesised $\mathrm{Na}-\mathrm{H}_{3} \mathrm{O}$ jarosite has an average composition of $\left[\begin{array}{llll}\mathrm{Na}_{0.57(3)} & \left(\mathrm{H}_{3} \mathrm{O}\right)_{0.36} & \left(\mathrm{H}_{2} \mathrm{O}\right)_{0.07}\end{array}\right]^{\mathrm{A}}$
$\mathrm{Fe}_{2.93(3)}\left(\mathrm{SO}_{4}\right)_{2}(\mathrm{OH})_{5.70}\left(\mathrm{H}_{2} \mathrm{O}\right)_{0.30}$ if deprotonation of $\mathrm{H}_{3} \mathrm{O}$ at the $A$ site and protonation of all four coordinating $\mathrm{OH}$ groups around a $\mathrm{Fe}$ vacancy are included in the formula calculation (Nielsen et al. 2008). Compositional variations between the single analyses are $5 \%$ for $\mathrm{Na}_{2} \mathrm{O}, 1 \%$ for $\mathrm{Fe}_{2} \mathrm{O}_{3}$ and $1 \%$ for $\mathrm{SO}_{3}$. The totals including calculated water contents of the single analysis are 100.4-101.3 wt\% (Table 2). It indicates that the employed EMPA method using low voltage and current, a large beam spot size, and short counting times could successfully minimize potential beam damage due to $\mathrm{Na}$ and $\mathrm{H}_{2} \mathrm{O}$ contents of the crystal.

\section{Crystal structure refinement}

Details of data collection and structure refinement are summarized in Table 1. The room-temperature structure was solved in space group $R \overline{3} m$ using direct methods. The space group choice $R \overline{3} m\left(R_{\mathrm{int}}=0.034\right)$ is in agreement with previous single-crystal studies of $\mathrm{Na}$ jarosite and $\mathrm{H}_{3} \mathrm{O}$ jarosite (Grohol et al. 2003; Nestola et al. 2013; Majzlan et al. 2004; Plášil et al. 2014; Spratt et al. 2014).

All non-hydrogen atoms could be located and their displacement factors were refined anisotropically. The hydrogen of the hydroxyl group was identified from the difference Fourier map and introduced in a subsequent refinement step. Hydrogen from $\mathrm{H}_{3} \mathrm{O}$ and $\mathrm{H}_{2} \mathrm{O}$ at the $A$ site could not be identified; a result that was expected because motion and disorder makes it difficult to locate hydrogen within the cavity surrounding the $A$ site (e.g. Spratt et al. 2014; Nielsen et al. 2008, 2011). The estimated residual electron density maxima for hydrogen should be very low
Table 2 Chemical composition from electron microprobe analysis

\begin{tabular}{|c|c|c|c|c|c|c|c|c|}
\hline & Mean & 1 & 2 & 3 & 4 & 5 & 6 & 7 \\
\hline \multicolumn{9}{|l|}{$\mathrm{Wt} \%$} \\
\hline $\mathrm{Na}_{2} \mathrm{O}$ & $3.7(2)$ & 3.55 & 3.83 & 3.81 & 3.98 & 3.54 & 3.53 & 3.68 \\
\hline $\mathrm{SO}_{3}$ & $33.7(5)$ & 33.96 & 33.98 & 33.59 & 33.43 & 33.78 & 33.76 & 33.74 \\
\hline $\mathrm{Fe}_{2} \mathrm{O}_{3}$ & $49.2(6)$ & 49.39 & 48.79 & 48.94 & 49.59 & 50.01 & 48.81 & 49.09 \\
\hline Sub total & $86.7(4)$ & 86.90 & 86.60 & 86.34 & 87.00 & 87.33 & 86.10 & 86.51 \\
\hline $\mathrm{H}_{2} \mathrm{O} *$ & 14.1(3) & 14.36 & 14.39 & 14.06 & 13.51 & 13.98 & 14.49 & 14.22 \\
\hline Total & $100.8(3)$ & 101.26 & 100.99 & 100.40 & 100.51 & 101.31 & 100.59 & 100.73 \\
\hline \multicolumn{9}{|l|}{ p.f.u. } \\
\hline $\mathrm{Na}$ & $0.57(3)$ & 0.54 & 0.58 & 0.59 & 0.62 & 0.54 & 0.54 & 0.56 \\
\hline $\mathrm{H}_{3} \mathrm{O}^{+}$ & $0.36(4)$ & 0.38 & 0.30 & 0.34 & 0.36 & 0.43 & 0.36 & 0.35 \\
\hline $\mathrm{H}_{2} \mathrm{O}^{\mathrm{A}}$ & $0.07(3)$ & 0.08 & 0.12 & 0.08 & 0.03 & 0.03 & 0.10 & 0.08 \\
\hline $\mathrm{Fe}$ & $2.93(3)$ & 2.92 & 2.88 & 2.92 & 2.97 & 2.97 & 2.90 & 2.92 \\
\hline $\mathrm{S}$ & $2.00(0)$ & 2.00 & 2.00 & 2.00 & 2.00 & 2.00 & 2.00 & 2.00 \\
\hline $\mathrm{OH}^{-}$ & $5.7(1)$ & 5.67 & 5.52 & 5.69 & 5.90 & 5.88 & 5.60 & 5.67 \\
\hline $\mathrm{H}_{2} \mathrm{O}^{\square}$ & $0.3(1)$ & 0.33 & 0.48 & 0.31 & 0.10 & 0.12 & 0.40 & 0.33 \\
\hline
\end{tabular}

Element contents (p.f.u.) derived from formula: $\left[\mathrm{Na}_{x}\left(\mathrm{H}_{3} \mathrm{O}\right)_{1-x-y}\left(\mathrm{H}_{2} \mathrm{O}\right)_{y}\right]^{\mathrm{A}} \mathrm{Fe}_{3-y}\left(\mathrm{SO}_{4}\right)_{2}(\mathrm{OH})_{6-4 y}\left(\mathrm{H}_{2} \mathrm{O}\right)_{4 y}^{\square}$ (see text)

wt $\% \mathrm{H}_{2} \mathrm{O}^{*}$ calculated from $\mathrm{H}_{3} \mathrm{O}^{+}+\mathrm{H}_{2} \mathrm{O}^{\mathrm{A}}+\mathrm{OH}^{-}+\mathrm{H}_{2} \mathrm{O}^{\square}$ with ${ }^{\mathrm{A}}=\mathrm{A}$ site and ${ }^{\square}=$ vacant $\mathrm{Fe}$ site 


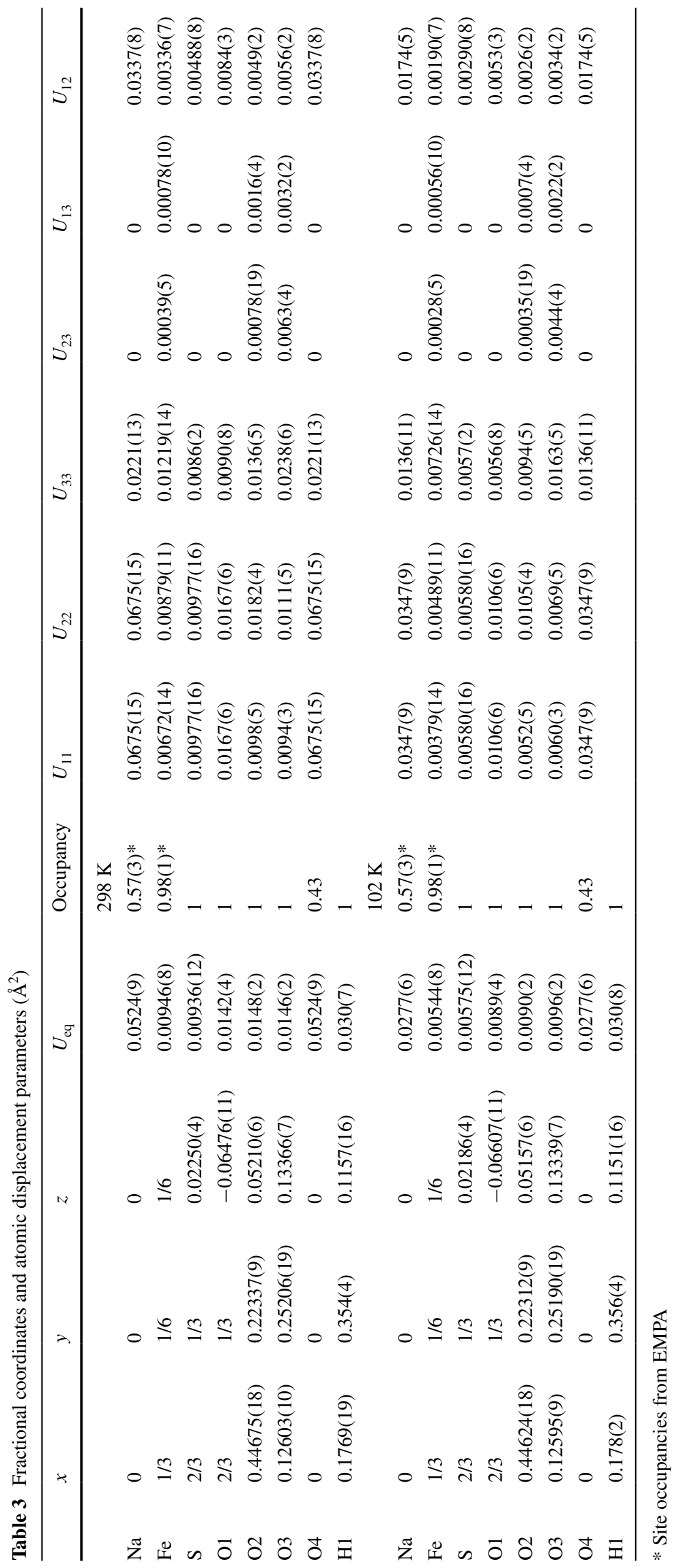


Table 4 Selected bond distances $(\AA)$, polyhedral volumes $\left(\AA^{3}\right)$ and distortion parameters

\begin{tabular}{|c|c|c|}
\hline & $298 \mathrm{~K}$ & $102 \mathrm{~K}$ \\
\hline$A-\mathrm{O} 3 \times 6$ & $2.7494(13)$ & $2.7368(12)$ \\
\hline$A-\mathrm{O} 2 \times 6$ & $2.9658(12)$ & $2.9582(11)$ \\
\hline$<A-\mathrm{O}>$ & 2.858 & 2.848 \\
\hline$A \mathrm{O}_{12}$ volume & 58.56 & 57.99 \\
\hline$A-\mathrm{O}$ bond length distortion & 0.0379 & 0.0389 \\
\hline$A \mathrm{O}_{12}$ quadratic elongation & 1.0085 & 1.0080 \\
\hline $\mathrm{Fe}-\mathrm{O} 2 \times 2$ & $2.0475(11)$ & $2.0467(11)$ \\
\hline $\mathrm{Fe}-\mathrm{O} 3 \times 4$ & $1.9885(5)$ & $1.9882(5)$ \\
\hline$<\mathrm{Fe}-\mathrm{O}>$ & 2.008 & 2.008 \\
\hline $\mathrm{FeO}_{6}$ volume & 10.78 & 10.77 \\
\hline $\mathrm{Fe}-\mathrm{O}$ bond length distortion & 0.0130 & 0.0129 \\
\hline $\mathrm{FeO}_{6}$ quadratic elongation & 1.0011 & 1.0013 \\
\hline $\mathrm{S}-\mathrm{O} 1$ & $1.460(2)$ & $1.465(2)$ \\
\hline $\mathrm{S}-\mathrm{O} 2 \times 3$ & $1.4807(11)$ & $1.4833(11)$ \\
\hline$<\mathrm{S}-\mathrm{O}>$ & 1.476 & 1.479 \\
\hline $\mathrm{SO}_{4}$ volume & 1.65 & 1.66 \\
\hline $\mathrm{S}-\mathrm{O}$ bond length distortion & 0.0052 & 0.0047 \\
\hline $\mathrm{SO}_{4}$ quadratic elongation & 1.0001 & 1.0000 \\
\hline
\end{tabular}

Bond length distortion after Baur (1974)

Quadratic elongation after Robinson et al. (1971)

( $<0.25 \mathrm{e} / \AA^{3}$ ) considering a $\mathrm{H}_{3} \mathrm{O} / \mathrm{H}_{2} \mathrm{O}$ content of $<50 \%$ at the $A$ site in this study and a fractional occupancy of 0.5 at the proposed $m$ site for hydronium hydrogen (Wyckoff site $18 \mathrm{~h}$, full site occupancy is 0.5 ; e.g. Plášil et al. 2014).

The occupancies of the $A$ and $B$ site were studied in two different ways. Firstly, EMPA data were used to set the occupancies for the $A$ site $(\mathrm{Na}=0.57$ and $\mathrm{O} 4=0.43)$ and for the $B$ site $(\mathrm{Fe}=0.98)$. The refinement results using these fixed site occupancies are shown in Tables 3 and 4. Secondly, occupancies were refined for the $A$ site $(\mathrm{Na}+\mathrm{O} 4=1)$ and $B$ site $(\mathrm{Fe}+$ vacancies $=1)$, and yielded occupancies of $\mathrm{Na}=0.53(3)$ and $\mathrm{Fe}=0.97(1)$ with a marginal change of the refinement statistics $\left(R_{1}=0.0179, \mathrm{w} R_{2}=0.0370\right.$, Goof $=1.109$ ).

An identical refinement strategy was carried out with the XRD data from the low-temperature experiment at $102 \mathrm{~K}$. No phase transition was observed, and the structure was refined in $R \overline{3} \mathrm{~m}$. The final refinement resulted in $R_{1}=0.0184, \mathrm{w} R_{2}=0.0367$ and $\mathrm{GooF}=1.124$ and data are shown in Tables 3 and 4. An additional refinement of the low-temperature analysis using $A$ and $B$ site occupancies as free variables converged to $\mathrm{Na}=0.51$ (3) $\mathrm{Fe}=0.97$ (1) with a rather similar $R_{1}=0.0184, w R_{2}=0.0361$ and $\mathrm{GooF}=1.121$. The Fe occupancies refined by the room- and low-temperature XRD data conform closely with the EMPA data. The refined Na occupancies by XRD are slightly lower than the EMPA data. It is assumed that non-refinable small contributions from the hydronium/water hydrogen could affect the refinement of the $A$ site occupancy.

The hydronium oxygen atom $\mathrm{O} 4$ was located at the $\overline{3} \mathrm{~m}$ site ( $3 a$ Wyckoff site, coordinates $0,0,0$ ) which is in agreement with $\mathrm{H}_{3} \mathrm{O}$ jarosite studies (Plášil et al. 2014; Majzlan et al. 2004). However, a potential displacement of O4 along the $c$ axis was discussed in previously published work (Wills and Harrison 1996; Majzlan et al. 2004; Spratt et al. 2014) because the hydronium ion has usually $3 m$ symmetry, which is inconsistent with $\overline{3} m$ symmetry of hydronium in $\mathrm{H}_{3} \mathrm{O}$ jarosite. An attempt was made to refine $\mathrm{O} 4$ at a $3 m$ site (coordinates $0,0, z)$. The refinement converged to $(0,0$, 0 ) which confirmed that the most probable position of the hydronium oxygen $\mathrm{O} 4$ is the $\overline{3} m$ site. Furthermore, anisotropic displacement factors with elongation along the $a-b$ plane do not support a displacement of the hydronium oxygen along the $c$ axis direction (Table $3, U_{11}=U_{22}>U_{33}$ ).

\section{Crystal structure at $298 \mathrm{~K}$ : comparison with $\mathrm{H}_{3} \mathrm{O}$ jarosite}

The major units of the jarosite structure are $\mathrm{Fe}(\mathrm{OH})_{4} \mathrm{O}_{2}-$ $\mathrm{SO}_{4}$ layers stacked in $c$ direction and $A \mathrm{O}_{12}$ polyhedra intercalated between successive $\mathrm{Fe}(\mathrm{OH})_{4} \mathrm{O}_{2}-\mathrm{SO}_{4}$ layers (Figs. 1, 2). In our study, the $A$ site is occupied with $\mathrm{Na}^{+}$and oxygen [from $\mathrm{H}_{3} \mathrm{O}^{+}+\mathrm{H}_{2} \mathrm{O}$ ] in a 57:43 ratio. The ionic radius of $\mathrm{Na}^{+}$is smaller than $\mathrm{H}_{3} \mathrm{O}^{+}\left({ }^{[12]} \mathrm{Na}^{+}=1.39 \AA\right.$, Shannon $1976 ;{ }^{[12]} \mathrm{H}_{3} \mathrm{O}^{+}=1.52 \AA$, Okada et al. 1987). Compared to $\mathrm{H}_{3} \mathrm{O}$ jarosite (e.g. Majzlan et al. 2004), incorporation of the smaller $\mathrm{Na}^{+}$cation causes a decrease in the unit cell parameters, in which $c$ decreases to a greater extent $(-1.7 \%)$ than $a(-0.4 \%)$, confirming the well-known observation that substitution of univalent cations at the $A$ site in jarosite results in strong variation of the $c$ parameter while the $a$ parameter experiences only minor changes (e.g. Menchetti and Sabelli 1976). Our unit cell data fall close to the linear $a-c$ trend refined from powder data of $\mathrm{Na}-\mathrm{H}_{3} \mathrm{O}$ jarosite solid solutions (Fig. 3 in Basciano and Peterson 2008).

The decrease in unit cell parameters is controlled by changes of the $A$ site environment (Fig. 2). The $A$ site is coordinated to 12 oxygens $(\mathrm{O} 2$ and $\mathrm{O} 3)$ forming an icosahedron. $\mathrm{O} 2$ corners $(\times 6)$ are shared by $\mathrm{FeO}_{6}$ and $\mathrm{SO}_{4}$ polyhedra, whereas $\mathrm{O} 3$ corners $(\times 6)$ are shared by two $\mathrm{FeO}_{6}$ polyhedra and hydrogen. All $A-\mathrm{O}$ bond lengths decrease compared to $\mathrm{H}_{3} \mathrm{O}$ jarosite $(\Delta A-03=-0.062 \AA, \Delta A-02=-0.036 \AA)$. In contrast, $\mathrm{SO}_{4}$ and $\mathrm{FeO}_{6}$ polyhedra show only minor changes and their bond lengths remain constant (this study: $\langle\mathrm{S}-\mathrm{O}\rangle=1.476 \AA$, $<\mathrm{Fe}-\mathrm{O}>=2.008 \AA ; \mathrm{H}_{3} \mathrm{O}$ jarosite: $<\mathrm{S}-\mathrm{O}>=1.476 \AA$, $<\mathrm{Fe}-$ $\mathrm{O}>=2.009 \AA$, Majzlan et al. 2004). As a result, the $A \mathrm{O}_{12}$ polyhedron for $\mathrm{Na}-\mathrm{H}_{3} \mathrm{O}$ jarosite becomes more regular and its edge lengths become more similar (Fig. 3a, b). Here, the longer polyhedron edges of $A \mathrm{O}_{12}$, that are not shared with $\mathrm{FeO}_{6}$ octahedra, change most with Na incorporation. 

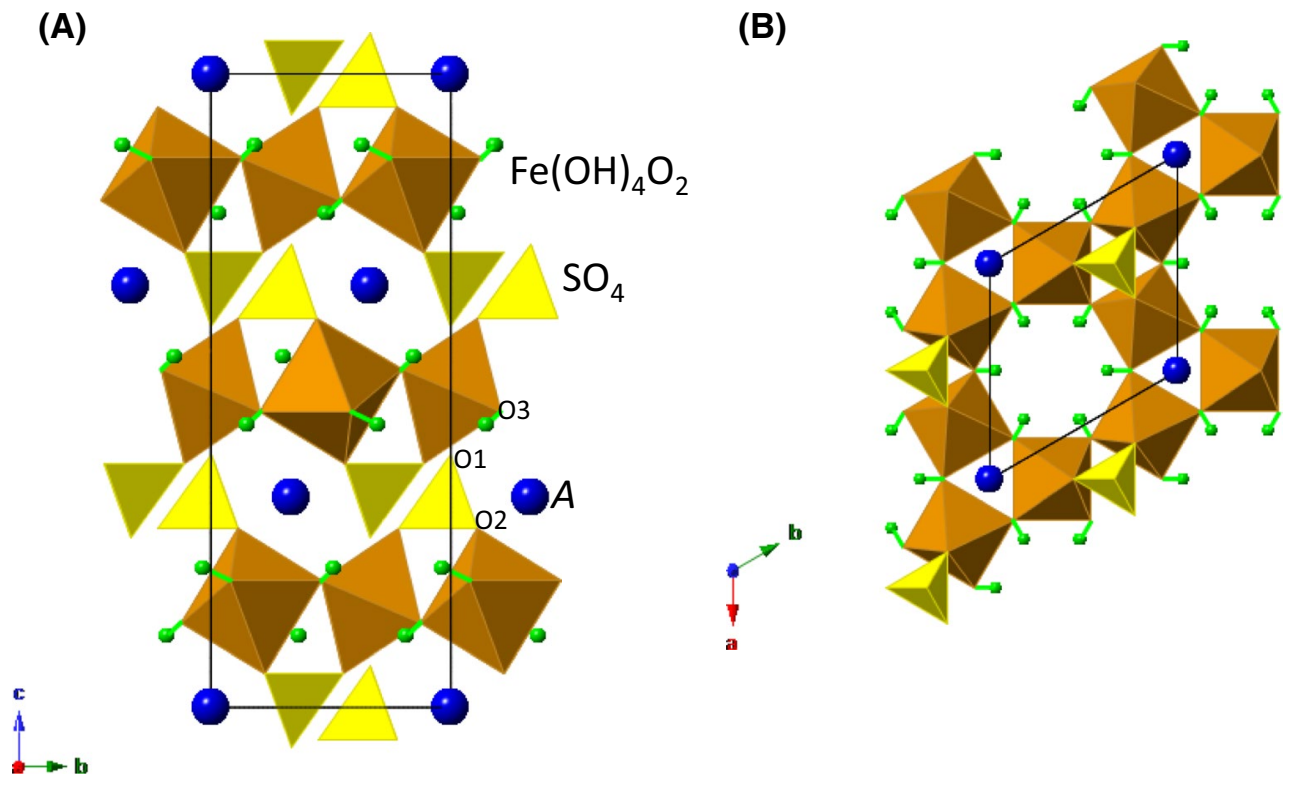

Fig. 1 Crystal structure of the jarosite group. (a) View along $a$ direction. (b) View along $c$ direction, $A$ sites and one neighbouring $\mathrm{Fe}(\mathrm{OH})_{4} \mathrm{O}_{2}-$ $\mathrm{SO}_{4}$ layer is shown

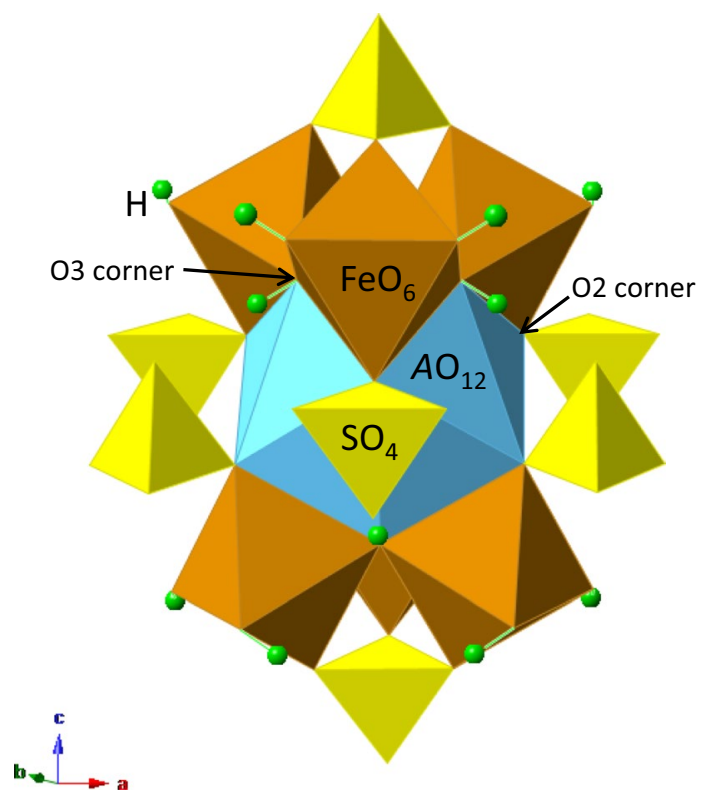

Fig. 2 Topology of the $A$ site environment. Neighbouring $\mathrm{FeO}_{6}$ octahedra share a face with the $A \mathrm{O}_{12}$ icosahedron. $\mathrm{SO}_{4}$ tetrahedra share corners with $\mathrm{FeO}_{6}$ and $A \mathrm{O}_{12}$. The largest flexibility of the structure lies along the non-face sharing $A \mathrm{O}_{12}$ edges

\section{Crystal structure at $298 \mathrm{~K}$ : comparison with general trends in the jarosite group}

It is useful to plot structural parameters versus unit cell parameter $c$. Figures 4,5 , and 6 show plots of bond lengths, bond length distortion and quadratic elongation versus $c$ for our study and recent crystal structure studies of the jarosite group. Arrows in the figures indicate changes with temperature. Bond length distortion was calculated after Baur (1974). Quadratic elongation was used as a measure of polyhedral distortion (Robinson et al. 1971). Here, calculations of the ideal coordination polyhedron were based on icosahedra for $A \mathrm{O}_{12}$, octahedra for $\mathrm{FeO}_{6}$ and tetrahedra for $\mathrm{SO}_{4}$.

Figures 4, 5, and 6 reveal that most trends are a linear function of the $c$ parameter reflecting the simple response of the jarosite structure for $A$ site substitutions. The $A-\mathrm{O}$ bond lengths decrease with smaller cation size, whereas $\mathrm{Fe}-\mathrm{O}$ and $\mathrm{S}-\mathrm{O}$ bonds remain relatively unchanged (Fig. 4). Our data match the linear trend very well. The linear change for $A-\mathrm{O}$ bond lengths is anisotropic, with $A-\mathrm{O} 3$ decreasing more strongly than $A-\mathrm{O} 2$ with smaller cation size, resulting in increasing bond length distortion around the $A$ site (Fig. 5). On the other hand, polyhedron distortion (quadratic elongation) of the $A \mathrm{O}_{12}$ icosahedron decreases with smaller cation size (Fig. 6). The $A \mathrm{O}_{12}$ polyhedron becomes more regular with decreasing cation size as length differences between polyhedron edges get smaller. As shown above for $\mathrm{H}_{3} \mathrm{O}$ jarosite and $\mathrm{Na}-\mathrm{H}_{3} \mathrm{O}$ jarosite (Fig. 3a, b), increased regularity is mainly a result of shortening of the less constrained polyhedron edges that are not shared with $\mathrm{FeO}_{6}$ octahedra. In contrast, the bond length distortion and polyhedral distortion of $\mathrm{FeO}_{6}$ and $\mathrm{SO}_{4}$ polyhedra remain unchanged throughout the jarosite group and are independent of substitution effects on the $A$ site (Figs. 5, 6). A possibility to modify the relative rigidity of the $\mathrm{Fe}(\mathrm{OH})_{4} \mathrm{O}_{2}-\mathrm{SO}_{4}$ network would be ordering of vacancies at the $B$ site which can be observed in monoclinic jarosite. Although not naturally occurring, 

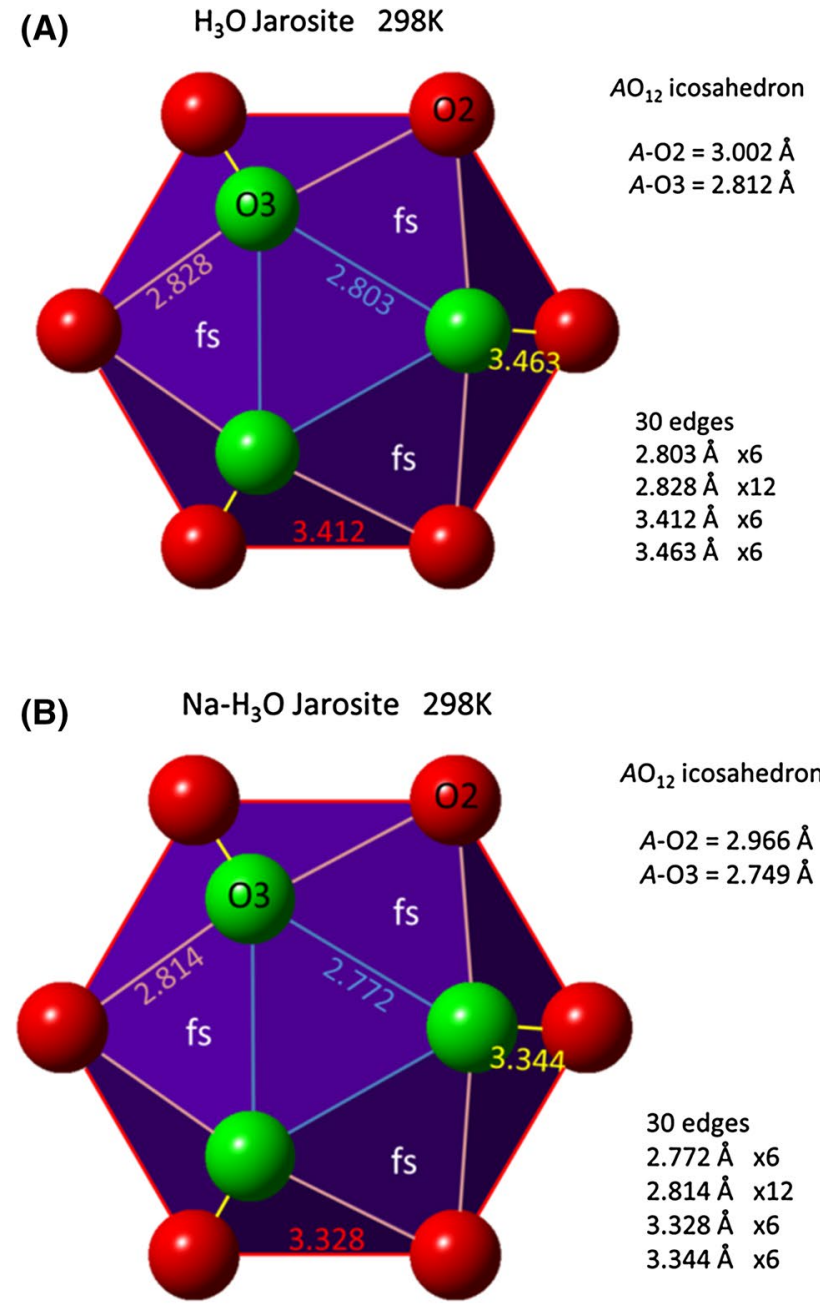

(C) $\quad \mathrm{Na}-\mathrm{H}_{3} \mathrm{O}$ Jarosite $102 \mathrm{~K}$

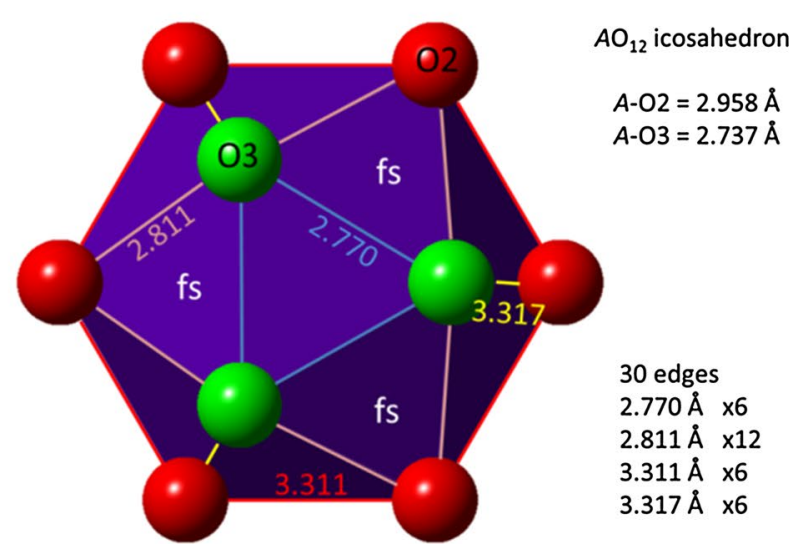

Fig. $3 A \mathrm{O}_{12}$ polyhedron of $\mathrm{Na}-\mathrm{H}_{3} \mathrm{O}$ jarosite. View along $c$ direction. fs indicates faces that are shared with a $\mathrm{FeO}_{6}$ octahedron and therefore less flexible. The regularity of the $A \mathrm{O}_{12}$ icosahedron increases with $\mathrm{Na}$ incorporation and lower temperature. Shortening is more pronounced for edges that are not shared with $\mathrm{FeO}_{6}$ octahedra (a) $\mathrm{H}_{3} \mathrm{O}$ jarosite at $298 \mathrm{~K}$ (Majzlan et al. 2004). (b) $\mathrm{Na}-\mathrm{H}_{3} \mathrm{O}$ jarosite at 298 K. (c) $\mathrm{Na}-\mathrm{H}_{3} \mathrm{O}$ jarosite at $102 \mathrm{~K}$

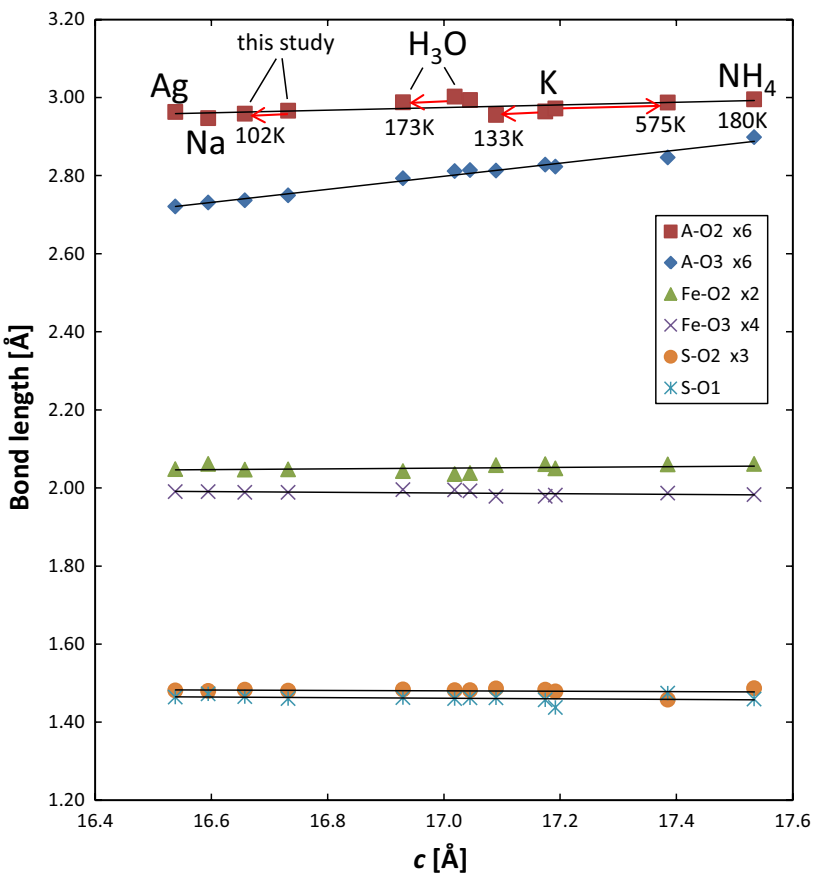

Fig. 4 Change of bond lengths versus unit cell parameter $c$ for jarosite group minerals. Room-temperature data are shown except assigned otherwise. Variation in composition and temperature show similar effects on bond lengths. Literature data: Ag jarosite Groat et al. (2003); Na jarosite Nestola et al. (2013); $\mathrm{H}_{3} \mathrm{O}$ jarosite Spratt et al. (2014) (173 K), Plášil et al. (2014), Majzlan et al. (2004); K jarosite Mills et al. (2013) 133-297 K, Xu et al. (2010a) 298-575 K; $\mathrm{NH}_{4}$ jarosite (Basciano and Peterson 2007)

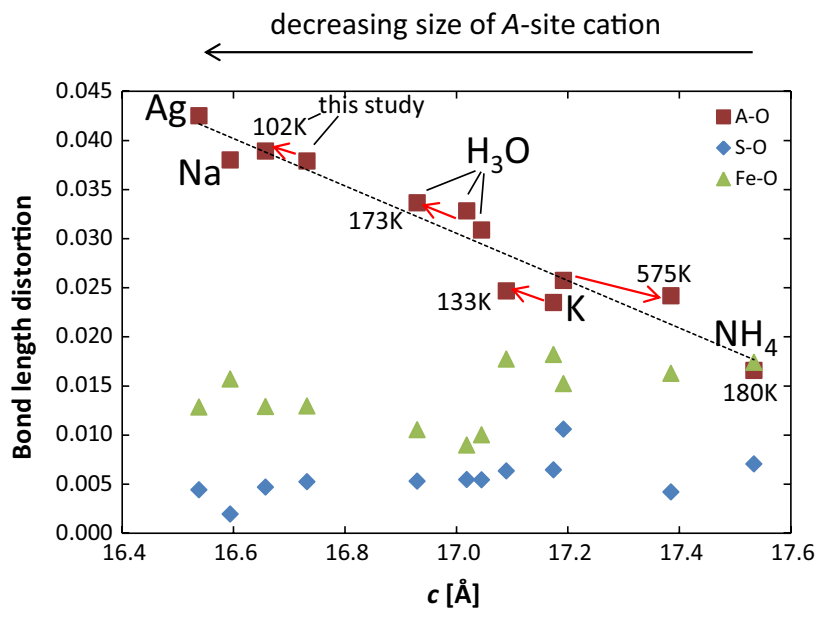

Fig. 5 Bond length distortion of jarosite group minerals versus unit cell parameter $c$. Room-temperature data are shown except assigned otherwise. Similar distortion effects can be observed with decreasing size of the $A$ cations and with lowering of the temperature. Literature data: Ag jarosite Groat et al. (2003); Na jarosite Nestola et al. (2013); $\mathrm{H}_{3} \mathrm{O}$ jarosite Spratt et al. (2014) (173 K), Plášil et al. (2014), Majzlan et al. (2004); K jarosite Mills et al. (2013) 133-297 K, Xu et al. (2010a) 298-575 K; $\mathrm{NH}_{4}$ jarosite (Basciano and Peterson 2007) 


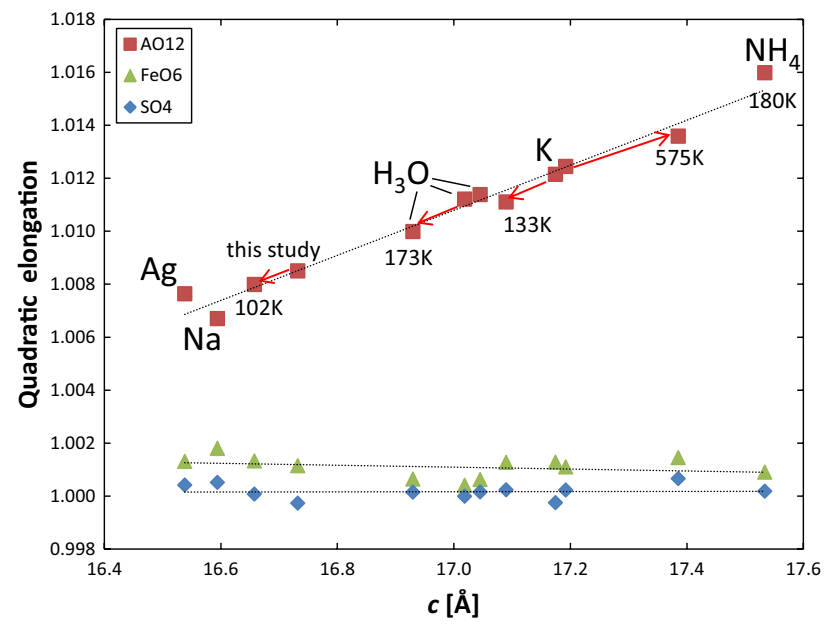

Fig. 6 Quadratic elongation versus $c$ axis for jarosite group minerals. Room-temperature data are shown except assigned otherwise. Variation in composition and temperature affects mainly distortion of the $A \mathrm{O}_{12}$ polyhedron. Literature data: Ag jarosite Groat et al. (2003); $\mathrm{Na}$ jarosite Nestola et al. (2013); $\mathrm{H}_{3} \mathrm{O}$ jarosite Spratt et al. (2014) (173 K), Plášil et al. (2014), Majzlan et al. (2004); K jarosite Mills et al. (2013) 133-297 K, Xu et al. (2010a) 298-575 K; $\mathrm{NH}_{4}$ jarosite (Basciano and Peterson 2007)

monoclinic $\mathrm{Na}-\mathrm{H}_{3} \mathrm{O}$ and $\mathrm{K}-\mathrm{H}_{3} \mathrm{O}$ jarosite with $\mathrm{C} 2 / \mathrm{m}$ symmetry could be synthesised (Scarlett et al. 2010; Grey et al. 2011, 2013). Vacancy ordering occurs at the Fe1 site, which is one of the two non-equivalent Fe sites. A major effect of the ordered disruption of the structure is an increase of the average bond length around the vacancy-bearing site $<\mathrm{Fe} 1-$ $\mathrm{O}>$, whereas the bond length of $\langle\mathrm{Fe} 2-\mathrm{O}>$ remains close to rhombohedral values of $\langle\mathrm{Fe}-\mathrm{O}\rangle$ (e.g. $\langle\mathrm{Fe} 1-\mathrm{O}\rangle=2.04 \AA$, $\langle\mathrm{Fe} 2-\mathrm{O}\rangle=2.01 \AA$, sample Najar-D1, Grey et al. 2011; $<\mathrm{Fe}-\mathrm{O}>=2.008 \AA$, this study).

A large thermal displacement $U_{\text {eq }}$ of $0.052 \mathrm{~A}^{2}$ was observed in this study for the $A$ site $(\mathrm{Na} / \mathrm{O} 4)$. Similar high values were reported by Nestola et al. (2013) for Na jarosite $\left(U_{e q}^{N a}=0.053 \AA^{2}\right)$. Excepting Ag jarosite $\left(U_{e q}^{A g}=0.031 \AA^{2}\right.$ Groat et al. 2003), there is a general trend of increasing $U_{\text {eq }}$ for smaller $A$ cations (Fig. 7), reflecting greater thermal motion of smaller cations within the large $A$ site. Anisotropic displacement factors for the $A$ site are more pronounced in the $a-b$ plane (Table 3, $U_{11}=U_{22}>U_{33}$ ), which can also be observed in $\mathrm{Ag}, \mathrm{H}_{3} \mathrm{O}$ and $\mathrm{K}$ jarosites (Groat et al. 2003; Plášil et al. 2014; Mills et al. 2013). Smaller $A$ cations induce a major shortening in the $c$ direction via the $A-\mathrm{O} 3$ bond and a minor shortening along the $a-b$ directions (via $A-\mathrm{O} 2$ ), possibly indicating that insufficient shortening of the $A-\mathrm{O} 2$ bond triggers increasingly stronger thermal motion in the $a-b$ plane for smaller cations.

\section{Crystal structure at $102 \mathrm{~K}$}

The low-temperature structure of $\mathrm{Na}-\mathrm{H}_{3} \mathrm{O}$ jarosite at $102 \mathrm{~K}$ showed a volume decrease of $0.5 \%\left(\Delta V=3.9 \AA^{3}\right)$

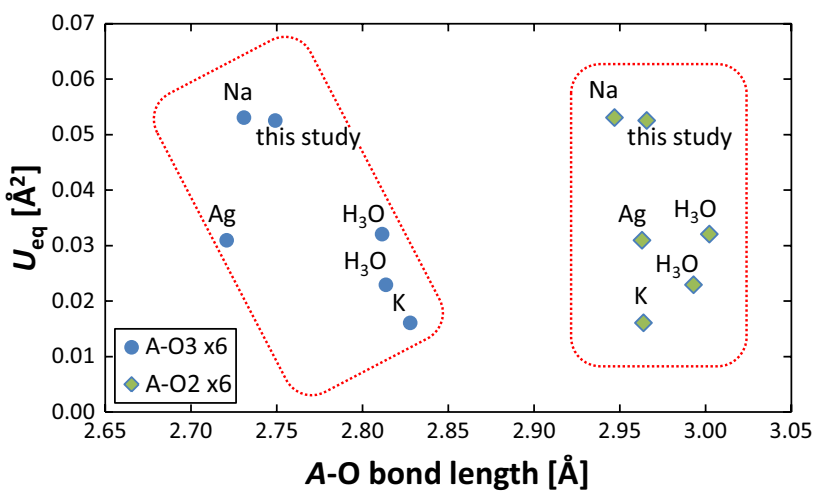

Fig. 7 Thermal displacement $U$ eq of the $A$ site in jarosite group minerals. Literature data: Ag jarosite Groat et al. (2003); Na jarosite Nestola et al. (2013); $\mathrm{H}_{3} \mathrm{O}$ jarosite Plášil et al. (2014), Majzlan et al. (2004); K jarosite Mills et al. (2013)

compared to the structure at room temperature. The volume reduction is mainly controlled by a change of the unit cell along the $c$ axis which decreases by $0.45 \%$, whereas the $a$ axis decreases only by $0.03 \%$. The strong axial anisotropy upon cooling mainly correlates with bond length changes in the $A \mathrm{O}_{12}$ polyhedron (Table 4). Upon cooling, the average bond length $\langle A-\mathrm{O}>$ decreases $-0.010 \AA$ whereas $<\mathrm{Fe}-\mathrm{O}>$ and $<\mathrm{S}-\mathrm{O}>$ show only minor changes $(<0.001$ and $0.003 \AA$, respectively). The main shortening occurs for $A-\mathrm{O} 3$ bonds which are major connectors of the $A$ site in $c$ direction. To compensate for lower temperatures, bond length distortion in the $A \mathrm{O}_{12}$ polyhedron increases slightly from 0.038 at $298 \mathrm{~K}$ to 0.039 at $102 \mathrm{~K}$ (Fig. 5). Polyhedral distortion of the $A \mathrm{O}_{12}$ icosahedron is decreasing from 1.0085 to 1.0080 (Fig. 6). It indicates that the $A \mathrm{O}_{12}$ polyhedron becomes more regular at lower temperature, in similar fashion as with incorporation of smaller $A$ cations. By comparing Fig. $3 \mathrm{~b}, \mathrm{c}$ it becomes clear that the cell edges of the icosahedron are less different upon cooling. In contrast, $\mathrm{FeO}_{6}$ octahedra and $\mathrm{SO}_{4}$ tetrahedra do not change significantly at lower temperatures.

Comparable temperature effects were observed for $\mathrm{K}$ jarosite (297-133 K, Mills et al. 2013; 298-575 K, Xu et al. 2010a) and can also be inferred for $\mathrm{H}_{3} \mathrm{O}$ jarosite by comparing studies undertaken at room temperature (Majzlan et al. 2004; Plášil et al. 2014) and 173 K (Spratt et al. 2014). Arrows in Figs. 4, 5, and 6 confirm the presence of comparable trends for $\mathrm{K}, \mathrm{H}_{3} \mathrm{O}$ and $\mathrm{Na}-\mathrm{H}_{3} \mathrm{O}$ jarosites, e.g. with lower temperatures: (1) bond length shortening within the $A \mathrm{O}_{12}$ polyhedron, (2) increasing bond length distortion of $A-\mathrm{O}$ bonds, (3) decreasing quadratic elongation (polyhedron distortion) for $A_{12}$ towards a more regular icosahedron, and (4) negligible changes in $\mathrm{FeO}_{6}$ and $\mathrm{SO}_{4}$ polyhedra. The controlling factor of the $A$ site deformation on the jarosite structure can also be observed with increasing pressure. A high-pressure study of $\mathrm{Na}$ jarosite (up to 8.8 
GPa, Nestola et al. 2013) showed that the main deformation mechanism is governed by shortening of $\mathrm{Na}-\mathrm{O}$ bonds with only minor or no shortening of $\mathrm{Fe}-\mathrm{O}$ and $\mathrm{S}-\mathrm{O}$ bonds. The large contraction of the $\mathrm{NaO}_{12}$ polyhedron with pressure is mainly responsible for strong shortening along the $c$ axis and minor shortening along the $a$ axis. A large axial cell anisotropy with increasing pressure was also reported for K jarosite (up to $8.1 \mathrm{GPa}$, Xu et al. 2010b).

\section{Implications for identification of jarosite minerals}

The jarosite crystal structure is clearly affected by nonambient conditions. Structural data are required for in situ XRD identification of jarosite in potentially lowtemperature environment, such as on the Mars surface. Understanding how the jarosite structure varies upon cooling is relevant because XRD patterns of jarosite group minerals at low temperature could mimic roomtemperature structures with smaller cations on the $A$ site; e.g. an initially assigned $\mathrm{Na}$ jarosite could actually be a $\mathrm{Na}-\mathrm{H}_{3} \mathrm{O}$ jarosite analysed at low temperature. Splitting of jarosite peaks in XRD patterns (e.g. indices 033 and 027, Scarlett et al. 2010) could indicate formation of monoclinic jarosite.

The structure data for room temperatures and low temperature are still limited given the wide range of solid solutions in the jarosite group. However, the available data for $\mathrm{K}, \mathrm{H}_{3} \mathrm{O}$ and $\mathrm{Na}-\mathrm{H}_{3} \mathrm{O}$ jarosite comprise important compositions commonly observed in nature. Structural changes within this compositional range are predictable given the linearity of the structural trends (Figs. 4, 5, 6). Therefore, interpolation of structural models for $\mathrm{K}-\mathrm{H}_{3} \mathrm{O}-\mathrm{Na}$ jarosite solid solutions at room temperature and low temperature should be a reasonable approach if there is lack of data for specific compositions.

\section{Conclusion}

It can be concluded that temperature- and compositionaldependent changes of bond lengths and distortion parameters follow similar patterns for all minerals in the jarosite group (Figs. 4, 5, 6). Structural changes upon cooling resemble effects caused by the incorporation of smaller cations at the $A$ site. Co-linear trends with composition and temperature suggest that the jarosite lattice activates a simple mechanism which is controlled by the flexibility of the large $A \mathrm{O}_{12}$ polyhedra and the rigidity of $\mathrm{Fe}(\mathrm{OH})_{4} \mathrm{O}_{2}-\mathrm{SO}_{4}$ layers. Similar structural effects can also be observed with increasing pressure (Nestola et al. 2013). The major flexibility of the $A \mathrm{O}_{12}$ polyhedron can be found around edges that are not shared with $\mathrm{FeO}_{6}$ octahedra. The environment around these non-sharing edges of the $A \mathrm{O}_{12}$ polyhedron is mainly responsible for structural changes with composition and temperature.

Acknowledgments The authors thank Mark Welch for helpful comments.

Open Access This article is distributed under the terms of the Creative Commons Attribution 4.0 International License (http://creativecommons.org/licenses/by/4.0/), which permits unrestricted use, distribution, and reproduction in any medium, provided you give appropriate credit to the original author(s) and the source, provide a link to the Creative Commons license, and indicate if changes were made.

\section{References}

Basciano LC, Peterson RC (2007) The crystal structure of ammoniojarosite, $\left(\mathrm{NH}_{4}\right) \mathrm{Fe}_{3}\left(\mathrm{SO}_{4}\right)_{2}(\mathrm{OH})_{6}$ and the crystal chemistry of the ammoniojarosite-hydronium jarosite solid solution series. Mineral Mag 71:427-441

Basciano LC, Peterson RC (2008) Crystal chemistry of the natrojarosite-jarosite and natrojarosite-hydronium jarosite solid-solution series: a synthetic study with full $\mathrm{Fe}$ site occupancy. Am Mineral 93:853-862

Baur WH (1974) The geometry of polyhedral distortions. Predictive relationships for the phosphate group. Acta Crystallogr A B30:1195-1215

Bayliss P, Kolitsch U, Nickel EH, Pring A (2010) Alunite supergroup: recommended nomenclature. Mineral Mag 74:919-927

Desborough GA, Smith KS, Lowers HA, Swayze GA, Hammarstrom JM, Diehl SF, Leinz RW, Driscoll RL (2010) Mineralogical and chemical characteristics of some natural jarosites. Geochim Cosmochim Acta 74:1041-1056

Dutrizac JE, Jambor, JL (2000) Jarosites and their application in hydrometallurgy. In: Alpers CN, Jambor JL, Nordstrom DK (eds) Sulfate minerals-crystallography, geochemistry, and environmental significance 40: 405-452. Reviews in Mineralogy and Geochemistry, Mineralogical Society of America, Chantilly, Virginia

Farrugia LJ (1999) WinGX: an integrated system of Windows Programs for the solution, refinement and analysis of single-crystal X-ray diffraction data. J Appl Crystallogr 32:837-838

Grey IE, Scarlett NVY, Bordet P, Brand HEA (2011) Jarosite-butlerite intergrowths in non-stoichiometric jarosites: crystal chemistry of monoclinic natrojarosite-hydronium jarosite phases. Mineral Mag 75:2775-2791

Grey IE, Scarlett NVY, Bordet P, Brand HEA (2013) Crystal chemistry and formation mechanism of non-stoichiometric monoclinic K-jarosites. Mineral Mag 77:249-268

Groat LA, Jambor JL, Pemberton BC (2003) The crystal structure of argentojarosite, $\mathrm{AgFe}_{3}\left(\mathrm{SO}_{4}\right)_{2}(\mathrm{OH})_{6}$. Can Mineral 41:921-928

Grohol D, Nocera DG, Papoutsakis D (2003) Magnetism of pure $\mathrm{Fe}$ jarosites. Phys Rev B Condens Matter Mater Phys 67: 064401/1-064401/13

Hudson-Edwards KA (2003) Sources, mineralogy, chemistry and fate of heavy metal-bearing particles in mining-affected river systems. Mineral Mag 67(2):204-217

Jamieson HE, Robinson C, Alpers CN, Nordstrom DK, Poustovetov A, Lowers HA (2005) The composition of coexisting jarositegroup minerals and water from the Richmond Mine, California. Can Mineral 43:1225-1242

Klingelhöfer G, Morris RV, Bernhardt B, Schroder C, Rodionov D, de Souza PAJ, Yen AS, Gellert R, Evlanov EN, Zubkov B, Foh 
J, Bonnes U, Kankeleit E, Gutlich P, Ming DW, Renz F, Wdowiak TJ, Squyres SW, Arvidson RE (2004) Jarosite and hematite at Meridiani Planum from Opportunity's Mössbauer spectrometer. Science 306:1740-1745

Majzlan J, Stevens R, Boerio-Goates J, Woodfield BF, Navrotsky A, Burns PC, Crawford MK, Amos TG (2004) Thermodynamic properties, low-temperature heat-capacity anomalies, and single-crystal X-ray refinement of hydronium jarosite, $\left(\mathrm{H}_{3} \mathrm{O}\right)$ $\mathrm{Fe}_{3}\left(\mathrm{SO}_{4}\right)_{2}(\mathrm{OH})_{6}$. Phys Chem Miner 31:518-531

Menchetti S, Sabelli C (1976) Crystal chemistry of the alunite series; crystal structure refinement of alunite and synthetic jarosite. Neues Jahrbuch fuer Mineralogie Monatshefte 9:406-417

Milliken RE, Swayze GA, Arvidson RE, Bishop JL, Clark RN, Ehlmann BL, Green RO, Grotzinger JP, Morris RV, Murchie SL, Mustard JF, Weitz C (2013) Opaline silica in young deposits on Mars. Geology 36:847-850

Mills SJ, Nestola F, Kahlenberg V, Christy AG, Hejny C, Redhammer G (2013) Looking for jarosite on Mars: the low temperature crystal structure of jarosite. Am Mineral 98:1966-1971

Morris RV, Klingelhöfer G, Schröder C, Rodionov DS, Yen A, Ming DW, de Souza PA Jr., Wdowiak T, Fleischer I, Gellert R et al (2006) Mössbauer mineralogy of rock, soil, and dust at Meridiani Planum, Mars: opportunity's journey across sulfate-rich outcrop, basaltic sand and dust, and hematite lag deposits. J Geophys Res 111: E12S15. DOI: 10.1029/2006JE002791

Nestola F, Mills SJ, Periotto B, Scandalo L (2013) The alunite supergroup under high pressure: the case of natrojarosite, $\mathrm{NaFe}_{3}\left(\mathrm{SO}_{4}\right)_{2}(\mathrm{OH})_{6}$. Mineral Mag 77:3007-3017

Nielsen UG, Majzlan J, Grey CP (2008) Determination and quantification of the local environments in stoichiometric and defect jarosite by solid-state ${ }^{2} \mathrm{H}$ NMR spectroscopy. Chem Mater 20:2234-2241

Nielsen UG, Heinmaa I, Samoson A, Majzlan J, Grey CP (2011) Insight into the local magnetic environments and deuteron mobility in jarosite $\left(\mathrm{AFe} 3\left(\mathrm{SO}_{4}\right) 2(\mathrm{OD}, \mathrm{OD} 2) 6, \mathrm{~A}=\mathrm{K}, \mathrm{Na}\right.$, $\mathrm{D} 3 \mathrm{O})$ and hydronium alunite $\left((\mathrm{D} 3 \mathrm{O}) \mathrm{Al} 3\left(\mathrm{SO}_{4}\right) 2(\mathrm{OD}) 6\right)$, from variable-temperature $2 \mathrm{H}$ MAS NMR spectroscopy. Chem Mater 23:3176-3187
Okada K, Soga H, Ossaka J, Otsuka N (1987) Syntheses of minamiite type compounds, $\mathrm{M}_{0.5} \mathrm{Al}_{3}\left(\mathrm{SO}_{4}\right)_{2}(\mathrm{OH})_{6}$ with $\mathrm{M}=\mathrm{Sr}^{2+}, \mathrm{Pb}^{2+}$ and $\mathrm{Ba}^{2+}$. Neues Jahrbuch für Mineralogie Monatshefte, 64-70

Plášil J, Škoda R, Fejfarova K, Čejka J, Kasatkin AV, Dušek M, Talla D, Lapčák L, Machovič V, Dini M (2014) Hydroniumjarosite, $\left(\mathrm{H}_{3} \mathrm{O}\right)^{+} \mathrm{Fe}_{3}\left(\mathrm{SO}_{4}\right)_{2}(\mathrm{OH})_{6}$, from Cerros Pintados, Chile: singlecrystal X-ray diffraction and vibrational spectroscopic study. Mineral Mag 78:535-547

Robinson K, Gibbs GV, Ribbe PH (1971) Quadratic elongation: a quantitative measure of distortion in coordination polyhedra. Science 172:567-570

Scarlett NVY, Grey IE, Brand HEA (2010) Ordering of iron vacancies in monoclinic jarosites. Am Mineral 95:1590-1593

Shannon RD (1976) Revised effective ionic radii and systematic studies of interatomic distances in halides and chalcogenides. Acta Crystallogr A A32:752-767

Sheldrick GM (2008) A short history of SHELX. Acta Crystallogr A A64:112-122

Spratt HJ, Avdeev M, Pfrunder MC, McMurtrie J, Rintoul L, Martens WN (2014) Location of hydrogen atoms in hydronium jarosite. Phys Chem Miner 41:505-517

Stoffregen RE, Alpers CN, Jambor JL (2000) Alunite-jarosite crystallography, thermodynamics and geochronology. In: Alpers CN, Jambor JL, Nordstrom DK (eds) Sulfate minerals-crystallography, geochemistry, and environmental significance 40: 453-479. Reviews in Mineralogy and Geochemistry, Mineralogical Society of America, Chantilly, Virginia

Wills AS, Harrison AH (1996) Structure and magnetism of hydronium jarosite, a model Kagomé antiferromagnet. J Chem Soc Faraday Trans 92:2161-2166

$\mathrm{Xu} \mathrm{H}$, Zhao Y, Vogel SC, Hickmott DD, Daemen LL, Hartl MA (2010a) Thermal expansion and decomposition of jarosite: a high-temperature neutron diffraction study. Phys Chem Miner 37:73-82

Xu H, Zhao Y, Zhang J, Wang Y, Hickmott DD, Daemen LL, Hartl MA, Wan L (2010b) Anisotropic elasticity of jarosite: a high-P synchrotron XRD study. Am Mineral 95:19-23 